\title{
Olive pomace valorization by Aspergillus species: lipase production using solid-state fermentation
}

\author{
Felisbela Oliveira, Cláudia Moreira, José Manuel Salgado, Luís Abrunhosa, \\ Armando Venâncio and Isabel Belo*
}

\begin{abstract}
BACKGROUND: Pollution by olive mill wastes is an important problem in the Mediterranean area and novel solutions for their proper management and valorization are needed. The aim of this work was to optimize a solid-state fermentation (SSF) process to produce lipase using olive pomace (OP) as the main source of nutrients by several Aspergillus spp. Optimized variables in two different designs were: ratio between olive pomace and wheat bran (OP:WB), $\mathrm{NaNO}_{3}, \mathrm{Czapek}$ nutrients, fermentation time, moisture content (MC) and temperature.

RESULTS: Results showed that the mixture OP:WB and MC were the most significant factors affecting lipase production for all fungi strains tested. With MC and temperature optimization, a 4.4-fold increase in $A$. ibericus lipase was achieved (90.5 $\pm 1.5 \mathrm{U}$ $\mathrm{g}^{-1}$ ), using a mixture of OP and WB at 1:1 ratio, $0.02 \mathrm{~g} \mathrm{NaNO}_{3} \mathrm{~g}^{-1}$ dry substrate, absence of Czapek nutrients, $60 \%$ of $\mathrm{MC}$ and incubation at $30^{\circ} \mathrm{C}$ for 7 days. For $A$. niger and $A$. tubingensis, highest lipase activity obtained was $56.6 \pm 5.4$ and $7.6 \pm 0.6 \mathrm{U} \mathrm{g}^{-1}$, respectively.
\end{abstract}

CONCLUSION: Aspergillus ibericus was found to be the most promising microorganism for lipase production using mixtures of OP and WB.

(c) 2015 Society of Chemical Industry

Keywords: olive pomace (OP); solid-state fermentation (SSF); A. ibericus; A. niger; A. tubingensis; lipase production

\section{INTRODUCTION}

Lipases (triacylglycerol acylhydrolases EC 3.1.1.3) are enzymes which catalyze the hydrolysis of fats and oils, releasing free fatty acids, diglycerides, monoglycerides and glycerol, over an oil-water interface; ${ }^{1,2}$ but they also mediate esterification, transesterification, acidolysis and alcoholysis. ${ }^{3}$ The global market for industrial enzymes was estimated to be US \$2 billion in 2004 . $^{1}$ Lipases comprise a wide variety of applications, such as in laundry and household detergents, food, textile, cosmetic, paper, agrochemicals, pharmaceuticals and even in biodiesel production. ${ }^{4,5}$ Lipases obtained from microorganisms are the most used for biotechnological applications. They may be obtained from bacteria, yeasts and filamentous fungi, through solid-state and submerged fermentation processes that use wild or recombinant strains. $^{5}$

Solid-state fermentation (SSF) is defined as a fermentation process that occurs in the absence or near absence of free water, but with sufficient moisture to support microorganism growth. ${ }^{6}$ In the last decade, an increasing interest in the development of SSF has been registered, mainly in applications for the bioremediation and biodegradation of toxic compounds and the detoxification of agricultural wastes, for example. Nonetheless, SSF is also being successfully applied in the production of enzymes, antibiotics, surfactants and other value-added products from agro-industrial wastes. ${ }^{7}$ In particular, SSF represents an interesting alternative for producing industrial enzymes at low cost. ${ }^{8}$ For example, the use of agro-industrial residues as substrate could result in a reduction in the cost of enzyme production, considering that the culture medium usually represents $25-50 \%$ of the total production costs. ${ }^{9}$ Castilho et al. ${ }^{10}$ found a total capital investment $78 \%$ higher for submerged fermentation (SmF) compared to SSF.

Olive mill wastes generated from olive oil extraction are a major environmental issue, particularly in Mediterranean area. Olive pomace (OP) is a sludgy waste generated by the olive oil two-phase extraction system. The two-phase extraction system is largely implemented in new olive mills, with OP being the most important residue produced. For example, in Portugal and Spain, this technology processes $86 \%$ and $90 \%$ of the olives for oil extraction, producing 250000 and 5 million tons of OP in 2014, respectively. ${ }^{11,12}$ Therefore, OP is a widely available and valueless residue that requires appropriate treatment and valorization. Biotechnological valorization approaches reported in the literature include composting, ${ }_{1}^{13}$ production of hydrogen, methane ${ }^{14,15}$ and ethanol as a biofuel; ${ }^{16,17}$ also polysaccharides, polymers ${ }^{18}$ and

Correspondence to: Isabel Belo, CEB - Centre of Biological Engineering, University of Minho, 4710-057 Braga, Portugal. E-mail: ibelo@deb.uminho.pt

CEB - Centre of Biological Engineering, University of Minho, 4710-057, Braga, Portugal 
enzymes such as lignocellulosic enzymes ${ }^{19}$ and lipase. ${ }^{20}$ OP is an acidic and very humid solid by-product, which is rich in organic matter, potassium, nitrogen, carbohydrates and phenols and also contains residual fats. ${ }^{21}$ Its properties make it an interesting substrate to induce lipase production by filamentous fungi under SSF. Recently, a growing interest in lipase production in low-cost agro-industrial wastes has emerged, and the use of substrates such as wheat bran (WB) has been proposed. ${ }^{22,23}$ The access to starch fraction and high protein concentration add extra value to WB compared to other lignocellulosic feedstocks. ${ }^{24}$

Filamentous fungi are interesting sources of lipase because they produce extracellular enzymes. ${ }^{25}$ Moreover, the hyphal mode of fungal growth and their tolerance to low water activity make fungi extremely efficient in the bioconversion of the solid substrate. ${ }^{7}$ The black aspergilli have a relevant importance in biotechnology since the most recognized species, Aspergillus niger, has GRAS status ('generally recognized as safe') from the Food and Drug Administration. Aspergillus ibericus is a new species from the black aspergilli group, which has been isolated from wine grapes. ${ }^{26}$ In previous studies, it has been demonstrated that $A$. ibericus is able to produce lipase under SmF. In a $2 \mathrm{~L}$ bioreactor, $A$. ibericus produced up to $8.3 \mathrm{U} \mathrm{mL}^{-1}$ of lipase using olive mill wastewater. ${ }^{27}$ Under solid-state fermentation using OP and winery wastes, Salgado et al. ${ }^{20}$ reported that $A$. ibericus produced $18.7 \mathrm{U}$ of lipase per gram of dry substrate.

In the work reported herein, OP was mixed with WB. The aim of the work was to optimize the production of lipase by $A$. ibericus MUM 03.49, A. niger MUM 03.58 and A. tubingensis MUM 06.152, under SSF. The process was optimized by evaluating parameters such as substrate composition (mixtures of OP and WB), amount of inorganic nitrogen supplementation, Czapek nutrients, fermentation time, moisture content (MC) and temperature.

\section{MATERIALS AND METHODS}

\section{Substrates}

OP samples were collected from a local two-phase olive mill plant in Vila Real, Portugal, in the 2011/2012 season, and stored at $-20^{\circ} \mathrm{C}$ for use throughout the study. OP characteristics were determined by Salgado et al., ${ }^{19}$ presenting an MC of $75.3 \pm 0.1 \%$ (w/w, wet basis) and a lipid concentration of $102.5 \pm 0.04 \mathrm{mg} \mathrm{g}^{-1}$ dry substrate. WB was purchased in a local supermarket and characteristics were determined as in the literature. ${ }^{24}$

\section{Biological material}

Aspergillus ibericus MUM 03.49, A. niger MUM 03.58 and A. tubingensis MUM 06.152 (MUM culture collection, Braga, Portugal) were used. These strains demonstrated high lipolytic activity in previous work. ${ }^{20}$ They were revived on malt extract agar (MEA) plates $\left(20 \mathrm{~g} \mathrm{~L}^{-1}\right.$ malt extract, $20 \mathrm{~g} \mathrm{~L}^{-1}$ glucose, $1 \mathrm{~g} \mathrm{~L}^{-1}$ peptone and $20 \mathrm{~g} \mathrm{~L}^{-1}$ agar) at $25^{\circ} \mathrm{C}$ from a frozen glycerol stock. Spore suspensions of the inoculum were prepared from 7-day-old culture plates with $1 \mathrm{~g} \mathrm{~L}^{-1}$ peptone solution (with $0.01 \mathrm{~g} \mathrm{~L}^{-1}$ Tween 80 ). The spore concentration of the suspension was adjusted to $10^{6}$ spores $\mathrm{mL}^{-1}$ using a Neubauer counting chamber.

\section{Optimization of SSF with Taguchi L9 orthogonal array}

SSFs were performed in cotton-plugged $500 \mathrm{~mL}$ Erlenmeyer flasks containing $30 \mathrm{~g}$ dried substrate. Initial MC was adjusted to $75 \%$ (w/w, wet basis) with distilled water when necessary. Flasks were autoclaved at $121^{\circ} \mathrm{C}$ for $15 \mathrm{~min}$, cooled, inoculated with $1 \mathrm{~mL}$ of inoculum suspension and incubated at an initial temperature of $25^{\circ} \mathrm{C}$. Initially, a Taguchi L9 orthogonal array was designed using Qualitek-4 software (Nutek Inc., USA), in order to study the effect of several factors on lipase activity (Table 1). Four factors were evaluated at three levels, with nine runs performed for each fungus. The four factors were: (i) ratio of OP:WB (1:0; $2: 1$ and 1:1, w/w); (ii) supplementation with $\mathrm{NaNO}_{3}(0.15 ; 0.3$ and $0.6 \mathrm{~g})$; (iii) supplementation with mineral nutrients (Czapek nutrients) $(0$ - no supplementation; $1 \times-1 \mathrm{~g} \mathrm{~L}^{-1} \mathrm{~K}_{2} \mathrm{HPO}_{4}, 0.5 \mathrm{~g} \mathrm{~L}^{-1} \mathrm{KCl}, 0.5 \mathrm{~g} \mathrm{~L}^{-1} \mathrm{MgSO}_{4}$. $7 \mathrm{H}_{2} \mathrm{O}$, $0.5 \mathrm{~g} \mathrm{~L}^{-1} \mathrm{CaCl} .2 \mathrm{H}_{2} \mathrm{O}, 0.01 \mathrm{~g} \mathrm{~L}^{-1} \mathrm{FeSO}_{4} .7 \mathrm{H}_{2} \mathrm{O}, 0.01 \mathrm{~g} \mathrm{~L}^{-1} \mathrm{ZnSO}_{4} .7 \mathrm{H}_{2} \mathrm{O}$ and $0.005 \mathrm{~g} \mathrm{~L}^{-1} \mathrm{CuSO}_{4} .5 \mathrm{H}_{2} \mathrm{O} ; 2 \times-$ same as $1 \times$ but with doubled concentration); and (iv) fermentation time (7, 14 and 21 days). Functions 'standard analysis' using 'average of results' and 'bigger is better' were used to evaluate the contribution of each factor on lipase activity and to determine the optimum conditions. Qualitek-4 was also used to perform analysis of variance (ANOVA) of the results obtained.

\section{Optimization of SSF with full factorial design}

A full factorial design $\left(3^{2}\right)$ was performed using Statistica 12 software (StatSoft, Tulsa, OK, USA) in order to study the influence of $M C$ and temperature on the production of lipase. Optimal conditions determined previously by Taguchi L9 orthogonal array were used as the starting point for this second experiment. As shown in Table 4, three levels were assigned to each factor: MC (70\%, 75\% and $80 \%)$ and temperature $\left(25,30\right.$ and $\left.35^{\circ} \mathrm{C}\right)$, performing nine runs in total. Polynomial equations were fitted to experimental values of lipase activity using Statistica 12 software (StatSoft) and best levels of MC and temperature that produced the maximum lipase activity were determined using the Solver application in Microsoft Excel 2010. The relationship between the dependent (lipase activity) and independent (MC and temperature) variables was established by the polynomial eq (1), as follows:

$$
y=a_{0}+a_{1} x_{1}+a_{2} x_{2}+a_{11} x_{1}^{2}+a_{22} x_{2}^{2}+a_{12} x_{1} x_{2}
$$

where $y$ is the predicted response, $x_{1}$ and $x_{2}$ are independent variables, $a_{0}$ is the intercept, $a_{1}$ and $a_{2}$ are linear coefficients, $a_{11}$ and $a_{22}$ are quadratic coefficients and $a_{12}$ is the interaction coefficient.

Finally, for each fungus at optimum temperature found, a final optimization of MC was conducted at levels between 35\% and $70 \%$, performing eight runs in total. Data obtained were statistically analyzed using SPSS (IBM SPSS Statistics, Version 22.0; IBM Corp., Armonk, NY, USA) to study the effect of variables on lipase production. Data were tested for homogeneity, and submitted to one-way ANOVA and a pair-wise multiple comparison procedure (Tukey's test) at a confidence level of $95 \%$.

\section{Lipase extraction and determination}

At the end of the incubation period, fermented substrates were homogenized with $150 \mathrm{~mL}$ of $10 \mathrm{~g} \mathrm{~L}^{-1} \mathrm{NaCl}$ and $5 \mathrm{~g} \mathrm{~L}^{-1}$ Triton $\mathrm{X}-100$ (solid:liquid ratio of $1: 5$ ) at $170 \mathrm{rpm}$ and $20^{\circ} \mathrm{C}$ for $2 \mathrm{~h}$ using a shaker. Homogenates were then centrifuged $(12000 \times g$ and $10 \mathrm{~min}$ at $4^{\circ} \mathrm{C}$ ) and filtered using Whatman No. 1 filter paper. The resulting enzymatic extracts were immediately used for lipase determination.

Extracellular lipase activity was determined by colorimetric assay, using $p$-nitrophenyl butyrate as described by Gomes et al. ${ }^{28}$ One unit of lipase activity $(U)$ was expressed as the amount of enzyme that produced $1 \mu \mathrm{mol} p$-nitrophenol $\mathrm{min}^{-1}$ under the 
Table 1. Factors and assigned levels in Taguchi L9 orthogonal array and experimental values of lipase activity obtained for the different filamentous fungi. Values are the mean \pm standard deviation (SD) of triplicate analysis

\begin{tabular}{|c|c|c|c|c|c|c|c|}
\hline \multirow[b]{2}{*}{ Run } & \multirow[b]{2}{*}{ OP:WB } & \multirow[b]{2}{*}{$\mathrm{NaNO}_{3}(\mathrm{~g})$} & \multirow[b]{2}{*}{ Czapek nutrients } & \multirow[b]{2}{*}{ Time (d) } & \multicolumn{3}{|c|}{ Experimental lipase activity $\pm S D\left(\cup^{-1}\right)$} \\
\hline & & & & & A. ibericus & A. niger & A. tubingensis \\
\hline 1 & $1: 0$ & 0.15 & 0 & 7 & $0 \pm 0$ & $0.2 \pm 0$ & $0.1 \pm 0$ \\
\hline 2 & $1: 0$ & 0.3 & $1 \mathrm{X}$ & 14 & $0 \pm 0$ & $0.5 \pm 0$ & $0.1 \pm 0$ \\
\hline 3 & $1: 0$ & 0.6 & $2 \mathrm{x}$ & 21 & $1.8 \pm 0.5$ & $0.2 \pm 0$ & $0.2 \pm 0.2$ \\
\hline $4^{\mathrm{a}}$ & $2: 1$ & 0.15 & $1 X$ & 21 & $1.0 \pm 0.3$ & $10.6 \pm 0.4$ & $5.1 \pm 0.6$ \\
\hline 5 & $2: 1$ & 0.3 & $2 X$ & 7 & $1.4 \pm 0.3$ & $2.3 \pm 0.6$ & $1.4 \pm 0.3$ \\
\hline $6^{\mathrm{b}}$ & $2: 1$ & 0.6 & 0 & 14 & $4.2 \pm 0.6$ & $10.9 \pm 1.9$ & $1.9 \pm 0.4$ \\
\hline 7 & $1: 1$ & 0.15 & $2 X$ & 14 & $11.9 \pm 1.0$ & $9.8 \pm 1.5$ & $1.8 \pm 0.6$ \\
\hline 8 & $1: 1$ & 0.3 & 0 & 21 & $13.2 \pm 1.1$ & $10.9 \pm 1.5$ & $3.7 \pm 0.3$ \\
\hline $9^{c}$ & $1: 1$ & 0.6 & $1 X$ & 7 & $18.7 \pm 0.3$ & $4.3 \pm 1.2$ & $1.3 \pm 0.4$ \\
\hline
\end{tabular}

\begin{tabular}{|c|c|c|c|c|c|}
\hline Fungus & Factor & Sum of squares & Variance & F-ratio & Percent P (\%) \\
\hline \multirow[t]{5}{*}{ A. ibericus } & OP:WB & 1058.5 & 529.2 & 1568.4 & 90.6 \\
\hline & $\mathrm{NaNO}_{3}$ & 81.5 & 40.7 & 120.7 & 6.9 \\
\hline & Czapek nutrients & 10.8 & 5.4 & 16.1 & 0.9 \\
\hline & Time & 11.3 & 5.7 & 16.8 & 0.9 \\
\hline & Error & 6.1 & 0.3 & - & 0.8 \\
\hline \multirow[t]{5}{*}{ A. niger } & OP:WB & 244.7 & 122.3 & 111.3 & 60.4 \\
\hline & $\mathrm{NaNO}_{3}$ & 17.5 & 8.7 & 8.0 & 3.8 \\
\hline & Czapek nutrients & 33.6 & 16.8 & 15.3 & 7.8 \\
\hline & Time & 96.1 & 48.0 & 43.7 & 23.4 \\
\hline & Error & 9.9 & 1.1 & - & 4.7 \\
\hline \multirow[t]{5}{*}{ A. tubingensis } & OP:WB & 34.8 & 17.4 & 124.7 & 49.3 \\
\hline & $\mathrm{NaNO}_{3}$ & 6.4 & 3.2 & 22.9 & 8.7 \\
\hline & Czapek nutrients & 5.0 & 2.5 & 18.0 & 6.8 \\
\hline & Time & 21.4 & 10.7 & 76.6 & 30.1 \\
\hline & Error & 2.5 & 0.1 & - & 5.2 \\
\hline
\end{tabular}

assay conditions. All the analyses were performed in triplicate. The lipase activity obtained was expressed as units per gram of dry substrate $\left(\mathrm{U} \mathrm{g}^{-1}\right)$.

\section{RESULTS AND DISCUSSION}

\section{Optimization with Taguchi L9 orthogonal array}

In general, all Aspergillus species were able to grow in all runs performed. However, in experiments conducted without WB, lipase activity was almost non-existent, probably due to the negative effect on microbial activity of OP organic acids and phenolic compounds, ${ }^{29}$ or to the low protein content of OP. Aspergillusibericus was found to be the best producer of lipase under the tested conditions, achieving lipase activities of $18.7 \pm 0.3 \mathrm{U} \mathrm{g}^{-1}$, as presented in Table 1. Also, Salgado et al. ${ }^{20}$ found a similar $A$. ibericus lipase production using OP and winery wastes at $75 \%$ MC.

The factor OP:WB ratio presented a greater effect on lipase activity. Analysis of variance from Table 2 showed the highest F-ratio values, and an influence (percent $\mathrm{P}$ ) of $90.6 \%$ for $A$. ibericus, $60.4 \%$ for A. niger and $49.3 \%$ for A. tubingensis. The combination of different substrates may favor fungal development and the production of enzymes, as presented in this study with the supplementation of OP with WB. It may act differently as a support matrix, as a nutrient source and as an inducer for the production of enzymes. ${ }^{30}$ For example, Kumar et al. ${ }^{31}$ found an optimum ratio of 1:1 of grease and WB, for lipase production using Penicillium chrysogenum, and concluded that fungi first uses WB for mycelial growth and then the grease waste.

According to F-ratio and percent of influence in Table 2, the second factor with the most pronounced effect on lipase activity was $\mathrm{NaNO}_{3}$ for $A$. ibericus and time for $A$. niger and $A$. tubingensis. It is well known that different nitrogen sources may enhance differently the production of lipases by microorganisms. For example, Sun and $\mathrm{Xu}^{32}$ reported that ammonium hydrogen phosphate had a positive effect on lipase production by Rhizopus chinensis, but that other nitrogen sources did not. In the present work, $\mathrm{NaNO}_{3}$ had a positive effect on lipase production for $A$. ibericus 
but the same was not observed for $A$. niger and $A$. tubingensis. On the contrary, fermentation time had a higher effect only for A. niger and A. tubingensis. Salgado et al. ${ }^{20}$ observed a maximum A. ibericus lipase production on the 5th day of a 20-day SSF of OP with exhausted grape marc. Using $A$. niger in different substrates, Edwinoliver et al. ${ }^{30}$ and Mahadik et al. ${ }^{33}$ found an optimum fermentation time of 4 and 5 days, respectively. The only factor that did not present a clear influence on lipase production was the Czapek nutrients. Kumar et al. ${ }^{31}$ also reported that Czapek Dox medium, used as salts and moisture facilitator for fungal growth, contributed to decrease lipase activity rather than to increase it. This work also showed that the optimum fermentation time for lipase production is extremely dependent on the fungus species used.

Table 3 presents the optimum fermentation conditions necessary to maximize the production of lipase for the fungi tested and the predicted lipase activity under those conditions, as determined by Qualitek-4 software. A production of $18.7 \mathrm{U} \mathrm{g}^{-1}$ for $A$. ibericus, $13.2 \mathrm{U} \mathrm{g}^{-1}$ for $A$. niger and $5.0 \mathrm{U} \mathrm{g}^{-1}$ for $A$. tubingensis was predicted.

\section{Optimization with full factorial design}

For a final optimization design, because some factors had a very small effect on lipase activity, SSF conditions were slightly changed: no Czapek nutrients were added for all strains (low
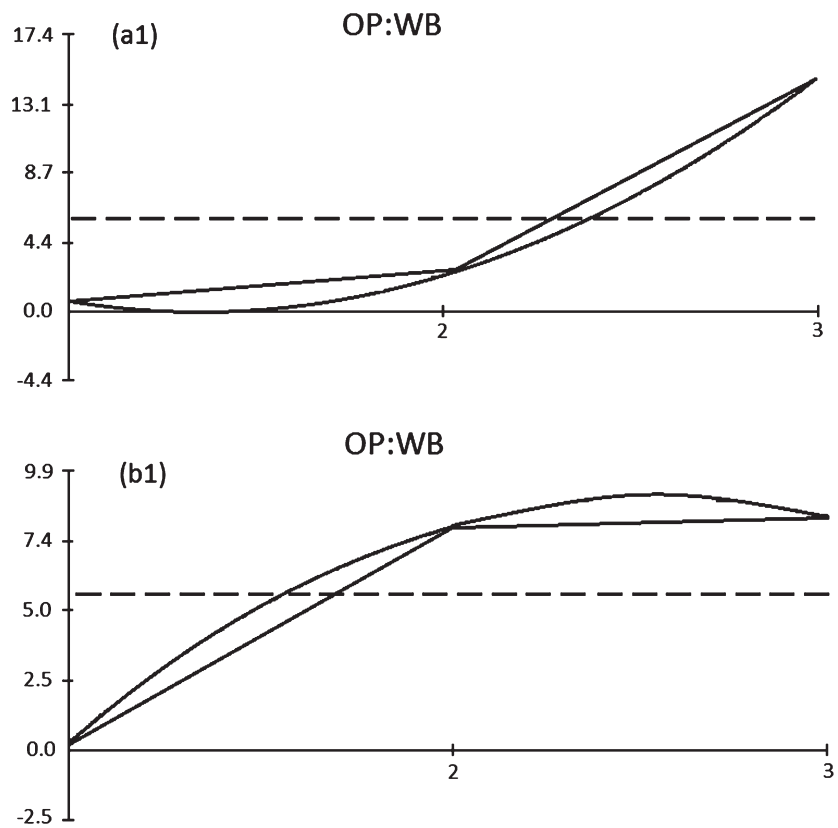
A. tubingensis MUM 06.152, using Taguchi L9 orthogonal array.
Table 3. Optimum level of factors obtained with Taguchi L9 orthogonal array and predicted lipase activity at optimum conditions

\begin{tabular}{|c|c|c|c|c|c|}
\hline Fungus & OP:WB & $\begin{array}{c}\mathrm{NaNO}_{3} \\
\text { (g) }\end{array}$ & $\begin{array}{c}\text { Czapek } \\
\text { nutrients }\end{array}$ & $\begin{array}{l}\text { Time } \\
\text { (d) }\end{array}$ & $\begin{array}{c}\text { Predicted } \\
\text { lipase }\left(\mathrm{U} \mathrm{g}^{-1}\right)\end{array}$ \\
\hline A. ibericus & $1: 1$ & 0.6 & $1 \times$ & 7 & 18.7 \\
\hline A. niger & 1:1 & 0.15 & 0 & 21 & 13.2 \\
\hline A. tubingensis & $2: 1$ & 0.15 & $1 \times$ & 21 & 5.1 \\
\hline
\end{tabular}

F-ratio and percent $\mathrm{P}$ - Table 2); and for $A$. niger, an OP:WB ratio of 2:1 and 14 days of fermentation were used (since effects were similar - Fig. 1.b) and because it was more convenient to use more $\mathrm{OP}$ and to reduce the fermentation time. In the case of $A$. ibericus and $A$. tubingensis, it was not necessary to change the levels of the factors OP:WB ratio and time, as shown in Fig. 1.

Table 4 presents experimental values of lipase activity from the full factorial design for the filamentous fungi tested, as a function of $\mathrm{MC}$ and temperature. Aspergillus ibericus and A. niger reached the highest lipase activity $\left(28.0 \pm 1.0 \mathrm{U} \mathrm{g}^{-1}\right.$ and $16.6 \pm 0.5 \mathrm{U} \mathrm{g}^{-1}$, respectively) at $70 \% \mathrm{MC}$ and $30^{\circ} \mathrm{C}$. For $A$. tubingensis a maximum of $6.7 \pm 0.6 \mathrm{U} \mathrm{g}^{-1}$ was obtained at $70 \% \mathrm{MC}$ and $25^{\circ} \mathrm{C}$. Compared to the previous results from optimization conditions using the

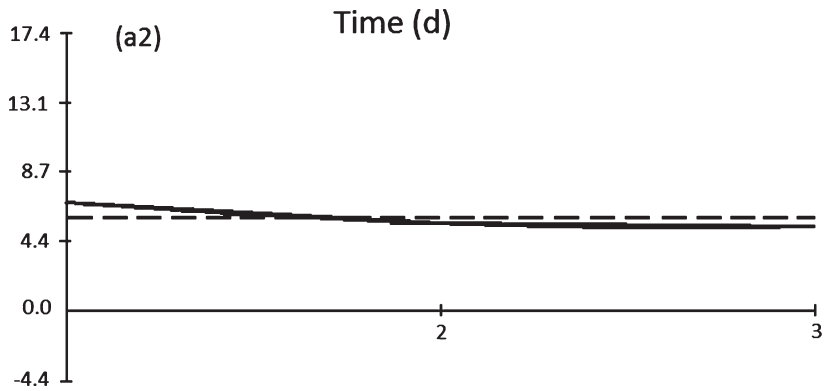

Time (d)

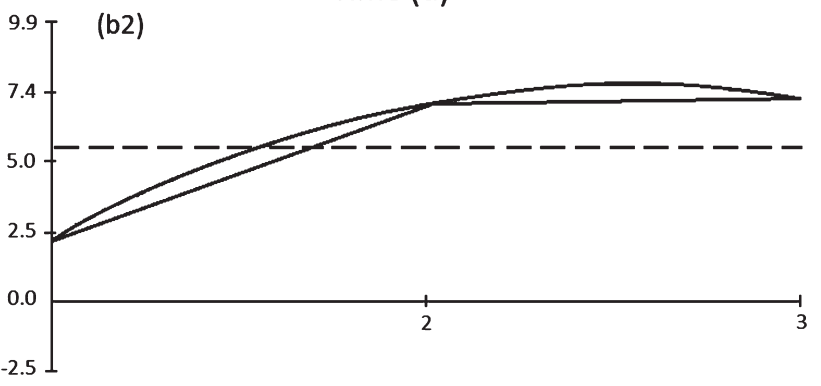

Time (d)

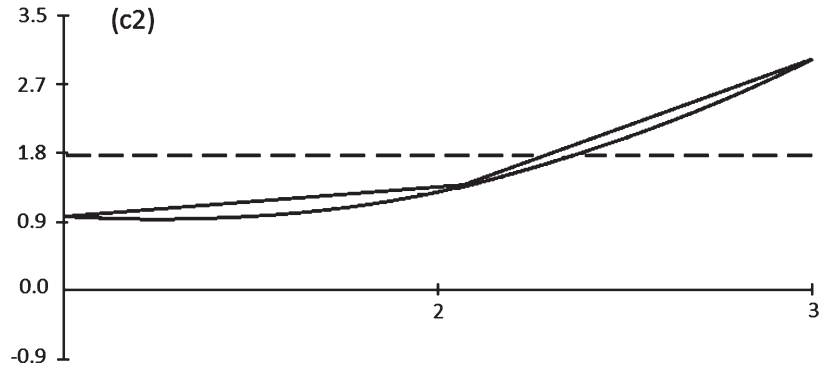

Figure 1. Effect of the factors (1) OP:WB ratio and (2) fermentation time on lipase production of (a) A. ibericus MUM 03.49, (b) A. niger MUM 03.58 and (c) 
Table 4. Factors and assigned levels of full factorial design. Experimental and predicted values of lipase activity obtained for each fungus. Values are the mean \pm standard deviation (SD) of triplicate analysis.

\begin{tabular}{|c|c|c|c|c|c|c|c|c|}
\hline \multirow[b]{3}{*}{ Run } & \multirow[b]{3}{*}{ MC (\%) } & \multirow[b]{3}{*}{ Temp. $\left({ }^{\circ} \mathrm{C}\right)$} & \multicolumn{6}{|c|}{ Values of lipase activity $\pm S D\left(\mathrm{U} \mathrm{g}^{-1}\right)$} \\
\hline & & & \multicolumn{2}{|c|}{ A. ibericus } & \multicolumn{2}{|c|}{ A. niger } & \multicolumn{2}{|c|}{ A.tubingensis } \\
\hline & & & Experimental & Predicted & Experimental & Predicted & Experimental & Predicted \\
\hline 1 & 70 & 25 & $23.2 \pm 5.2$ & 24.9 & $13.9 \pm 1.2$ & 14.4 & $6.7 \pm 0.6$ & 6.5 \\
\hline 2 & 70 & 30 & $28.0 \pm 0.6$ & 27.2 & $16.6 \pm 0.5$ & 16.1 & $5.2 \pm 0.6$ & 5.0 \\
\hline 3 & 70 & 35 & $16.7 \pm 1.1$ & 16.4 & $15.8 \pm 0.8$ & 15.3 & $2.6 \pm 0.6$ & 2.6 \\
\hline 4 & 75 & 25 & $20.8 \pm 1.0$ & 19.3 & $10.1 \pm 0.7$ & 8.8 & $5.9 \pm 1.1$ & 5.6 \\
\hline 5 & 75 & 30 & $22.9 \pm 1.5$ & 22.4 & $9.6 \pm 0.9$ & 9.5 & $4.8 \pm 1.0$ & 5.2 \\
\hline 6 & 75 & 35 & $9.8 \pm 0.6$ & 12.4 & $6.9 \pm 0.4$ & 7.7 & $4.3 \pm 1.1$ & 3.8 \\
\hline 7 & 80 & 25 & $6.8 \pm 1.1$ & 7.1 & $3.6 \pm 0.8$ & 3.9 & $1.9 \pm 0.3$ & 2.0 \\
\hline 8 & 80 & 30 & $9.0 \pm 0.5$ & 10.9 & $3.7 \pm 0.5$ & 3.7 & $3.3 \pm 0.2$ & 2.7 \\
\hline 9 & 80 & 35 & $3.2 \pm 0.2$ & 1.6 & $1.7 \pm 0.4$ & 0.9 & $2.2 \pm 0.2$ & 2.4 \\
\hline
\end{tabular}

(a)

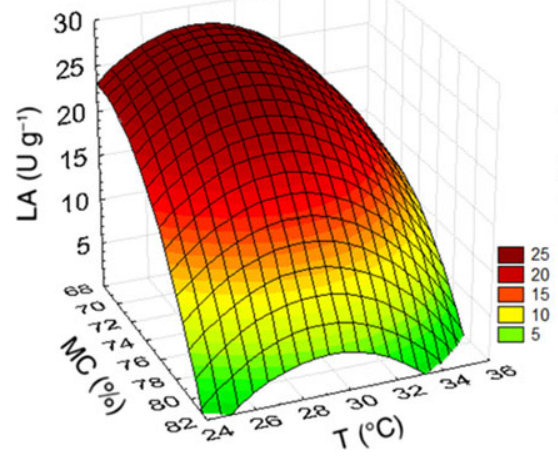

(b)

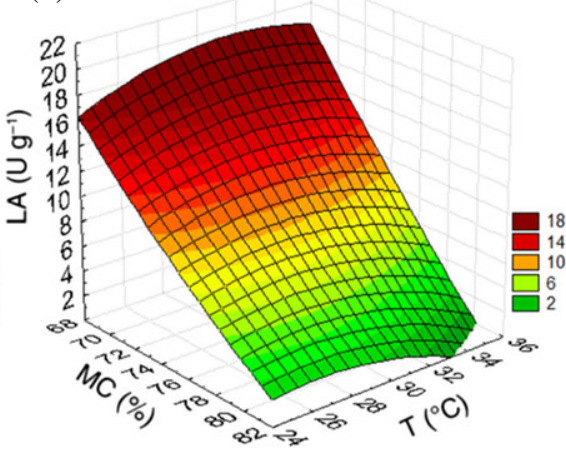

(c)

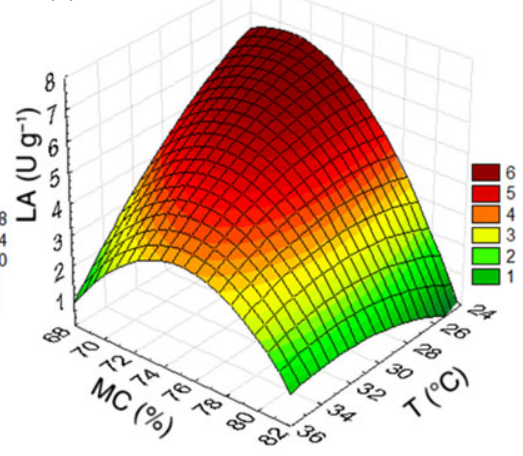

\begin{tabular}{lll}
\hline \multicolumn{1}{c}{ Fungus } & \multicolumn{1}{c}{ Equation } \\
\hline a) & A. ibericus & $\mathrm{LA}=-753.07+17.52 \mathrm{MC}+12.67 T-0.13 \mathrm{MC}^{2}-0.26 T^{2}+0.03 \mathrm{MCT}$ \\
b) & A. niger & $\mathrm{LA}=55.92-2.31 \mathrm{MC}+5.91 T+0.015 \mathrm{MC}^{2}-0.05 T^{2}-0.04 \mathrm{MCT}$ \\
c) & A. tubingensis & $\mathrm{LA}=-197.58+6.60 \mathrm{MC}-2.22 T-0.05 \mathrm{MC}^{2}-0.02 T^{2}+0.04 \mathrm{MCT}$ \\
\hline
\end{tabular}

Figure 2. Response surfaces of lipase activity (LA) as a function of moisture content (MC) and temperature ( $T$ ) according to the polynomial equations of (a) A. ibericus MUM 03.49, (b) A. niger MUM 03.58 and (c) A. tubingensis MUM 06.152.

Taguchi design, these results correspond to an increase in lipase production of $35 \%$ for $A$. ibericus, $64 \%$ for $A$. niger and $14 \%$ for $A$. tubingensis, by $\mathrm{MC}$ and temperature optimization.

The effects of those factors on lipase production were determined using Statistica software and it was observed that an increase of MC from $70 \%$ to $80 \%$ had a negative effect $(P<0.005)$ on lipase production by $A$. ibericus and A. niger, but was insignificant $(P>0.05)$ for $A$. tubingensis. Concerning temperature, a significant effect on lipase production was only observed for $A$. ibericus $(P<0.05)$. In other works, MC was also considered one of the most important factors affecting SSF processes, ${ }^{34}$ as well as temperature. Maximum saturation of the enzyme active site occurs at an optimum temperature, as enzymes become denatured at high temperature. Also at high temperature, protease production occurred, denaturing the enzymes. ${ }^{31}$ However, at lower temperature, microorganism growth slows down and, consequently, enzyme production.

Next, polynomial equations as a function of $\mathrm{MC}$ and temperature $(T)$ were fitted to the experimental values of lipase activity (LA) for each fungus (Fig. 2). ANOVA indicated a good fitting of the equations to the experimental values $\left(R^{2}>0.96\right)$, with the exception of $A$. tubingensis $\left(R^{2}<0.80\right)$. According to the model equations, the variation of LA with $\mathrm{MC}$ and temperature were represented as response surface plots, using Statistica software (Fig. 2). In this way the negative effect on LA of increasing MC levels and the existence of optimum values of MC and temperature, for which LA is maximized, using Solver application, can be clearly observed (Fig. 2 and Table 5). In general, results revealed that optimum values of temperature were around $30^{\circ} \mathrm{C}$ for $A$. ibericus and A. niger, and $25^{\circ} \mathrm{C}$ for $A$. tubingensis, but that the optimum MC was close to the lower level of the experimental design for all strains (around 70\%). Thus further experiments with MC lower than $70 \%$ were conducted to find the optimum.

Figure 3 presents the results of $L A$ as a function of $M C$ for these experiments. Lipase production was significantly higher for all strains at MC values lower than $70 \%(P<0.0001)$ and a maximum was obtained at $60 \%, 50 \%$ and $35 \%$ for $A$. ibericus, $A$. niger and A.tubingensis, respectively. Comparing with $\mathrm{MC}$ at $70 \%$, a threefold increase in lipase production was observed for A. ibericus, sevenfold for A. niger and fourfold for A.tubingensis, yielding significantly higher lipase production. Again, A. ibericus produced more lipase $\left(90.5 \pm 1.5 \mathrm{U} \mathrm{g}^{-1}\right)$ than A.niger 
Table 5. ANOVA of the polynomial equations and optimum predicted conditions and respective lipase activity for each fungus

\begin{tabular}{|c|c|c|c|c|c|c|c|c|c|}
\hline \multirow[b]{2}{*}{ Fungus } & \multicolumn{6}{|c|}{ ANOVA } & \multicolumn{3}{|c|}{ Optimum predicted } \\
\hline & $R^{2}$ & $R^{2}$ adjusted & SS equation & SS residual & $F$-value & $P$-value & MC (\%) & $\mathrm{T}\left({ }^{\circ} \mathrm{C}\right)$ & $\operatorname{LA}\left(\mathrm{Ug}^{-1}\right)$ \\
\hline A. ibericus & 0.9654 & 0.9308 & 580.16 & 20.80 & 27.89 & 0.0035 & 68.7 & 28.3 & 28.1 \\
\hline A. niger & 0.9692 & 0.9383 & 236.58 & 7.53 & 31.44 & 0.0028 & 70.0 & 30.9 & 16.2 \\
\hline A. tubingensis & 0.7603 & 0.5205 & 17.10 & 5.39 & 3.17 & 0.1449 & 70.9 & 25.0 & 6.6 \\
\hline
\end{tabular}
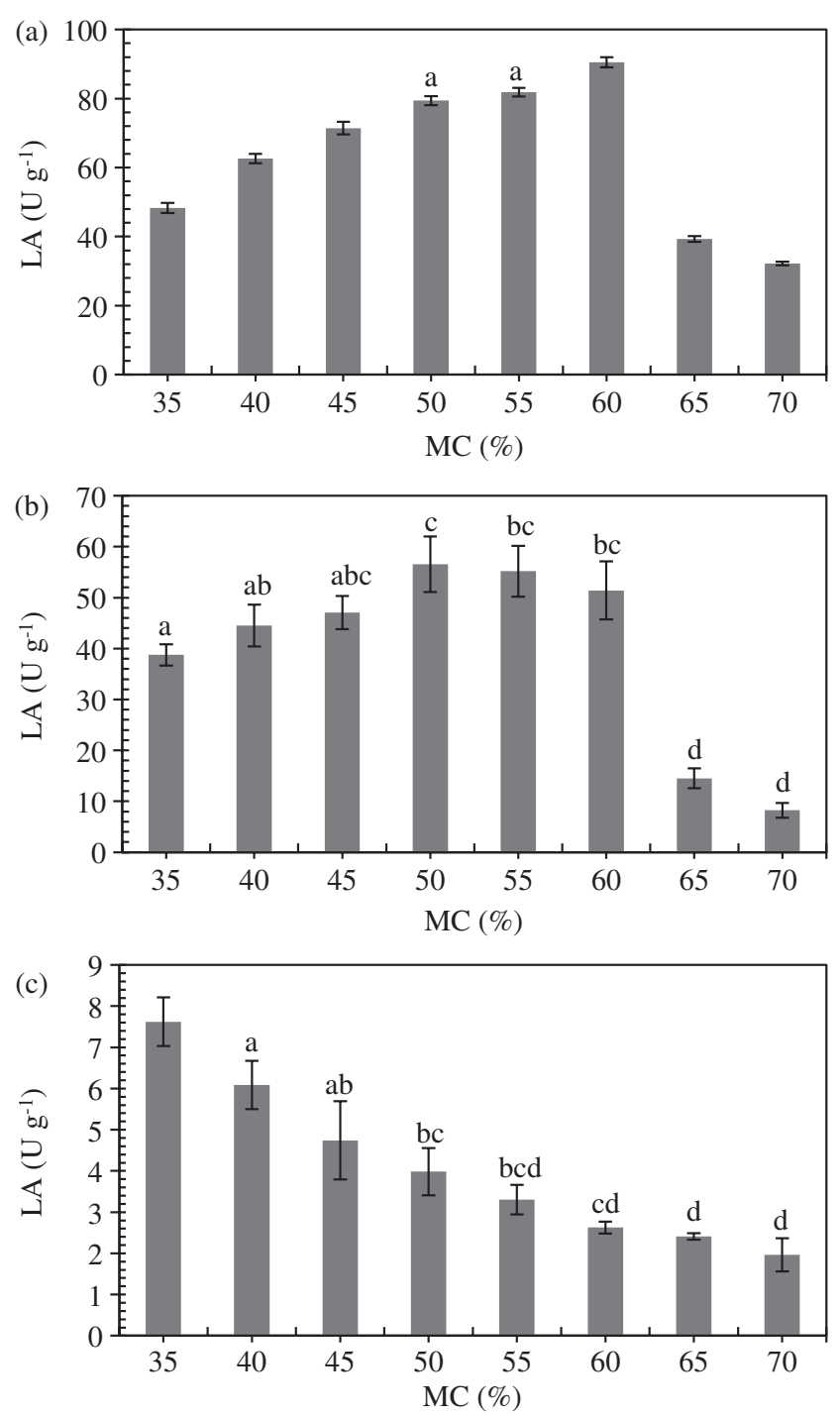

Figure 3. Influence of moisture content (MC) on lipase activity (LA) of (a) A. ibericus MUM 03.49, (b) A. niger MUM 03.58 and (c) A. tubingensis MUM 06.152. Depicted values are the mean of triplicate analysis \pm standard deviation. Means with the same letter do not differ significantly at $P>0.05$ $(t$-test).

$\left(56.6 \pm 5.4 \mathrm{U} \mathrm{g}^{-1}\right)$ and $A$. tubingensis $\left(7.6 \pm 0.6 \mathrm{U} \mathrm{g}^{-1}\right)$. Compared to A. ibericus lipase production from Taguchi design (at 75\% MC and at $\left.25^{\circ} \mathrm{C}\right), 20.8 \pm 1.0 \mathrm{U} \mathrm{g}^{-1}$, a 4.4 -fold increase was found.

The observed decrease of lipase activity with increasing MC has been observed by other researchers as well, $32,35-37$ and has been attributed to the impact of moisture on the physical properties of the solid substrate. ${ }^{38}$ High MC decreases substrate porosity, alters substrate particle structure, promotes development of stickiness and reduces gas volume and exchange, leading to oxygen diffusion limitation in the substrate layer, ${ }^{30,32,34,39}$ and microbial growth decreases. ${ }^{39}$ This study revealed the great importance of performing SSF at optimum MC to improve lipase production.

In general, after the whole optimization process, A. ibericus continued to be the best lipase producer, and a final increase of 4.4 fold in lipase production was achieved as a result of MC and temperature optimization. The obtained maximum lipase activities $\left(90.5 \pm 1.5 \mathrm{U} \mathrm{g}^{-1}\right.$ for A. ibericus and $56.6 \pm 5.4 \mathrm{U} \mathrm{g}^{-1}$ for A. niger) were higher than those obtained by other researchers, which also used SFF and filamentous fungi to produce lipase. For example, Falony et al. ${ }^{23}$ reported a lipase activity of $9.1 \mathrm{U} \mathrm{g}^{-1}$ at $65 \%$ MC with A. niger using WB with olive oil as inductor; Gutarra et al..$^{25}$ obtained a lipase production of $19.6 \mathrm{U} \mathrm{g}^{-1}$ in $72 \mathrm{~h}$ at $30^{\circ} \mathrm{C}$ growing Penicillium simplicissimum in babassu cake supplemented with sugar cane molasses at $70 \% \mathrm{MC}$; and Sun and $\mathrm{Xu}^{32}$ reported the production of $24.5 \mathrm{U} \mathrm{g}^{-1}$ by Rhizopus chinensis in wheat flour with WB at $70 \% \mathrm{MC}$.

As mentioned previously, A. ibericus is also capable of producing lipase under SmF using another olive residue: olive mill wastewater. The maximum concentration of lipase activity obtained in that case was $8.3 \mathrm{U} \mathrm{mL}^{-1},{ }^{27}$ which was approximately 1.9 -fold less than that obtained in the present work via SSF of OP:WB with A. ibericus (15.6 $\mathrm{U} \mathrm{mL}^{-1}$ in the extracting solution). These results agree with other researchers, which also reported that SSF indeed leads to higher lipase concentration than $\mathrm{SmF}^{23,40}$ Additionally, for A. ibericus, the observed optimum MC $(60 \%)$ turned out to be very convenient because it is exactly the MC obtained when OP and WB are mixed at a ratio of $1: 1$, thereby contributing to the reduction of costs and simplification of an eventual process at a large scale.

\section{CONCLUSIONS}

Substrate ratio of OP:WB and MC were found to be the most critical factors for lipase production by SSF with Aspergillus spp. Using Taguchi design, A. ibericus lipase production of $20.8 \pm 1.0$ $\mathrm{U} \mathrm{g}^{-1}$ was achieved, but after the subsequent optimization of MC and temperature a lipolytic activity of $90.5 \pm 1.5 \mathrm{U} \mathrm{g}^{-1}$ was attained, corresponding to 4.4 -fold increase in lipase production. The optimum conditions were OP:WB in a 1:1 ratio, $0.02 \mathrm{~g} \mathrm{NaNO}_{3}$ $\mathrm{g}^{-1}$ dry substrate, absence of Czapek nutrients, $60 \%$ of MC and incubation at $30^{\circ} \mathrm{C}$ for 7 days. Aspergillus ibericus was found to be the best lipase producer among the tested strains, being a promising microorganism for the production of this enzyme under SSF of OP with WB, and enabling an interesting approach for OP valorization.

\section{ACKNOWLEDGEMENTS}

Felisbela Oliveira and José Manuel Salgado acknowledge financial support from Fundação para a Ciência e Tecnologia (FCT) of Portugal through grants SFRH/BD/87953/2012 
and SFRH/BPD/84440/2012, respectively. Luís Abrunhosa was supported by grant UMINHO/BPD/51/2015 from project UID/BIO/04469/2013, financed by FCT/MEC (OE). The authors thank the FCT Strategic Project of UID/BIO/04469/2013 unit, the project RECI/BBB-EBI/0179/2012 (FCOMP-01-0124-FEDER-027462) and the project 'Biolnd - Biotechnology and Bioengineering for improved Industrial and Agro-Food processes', REF. NORTE-07-0124-FEDER-000028, co-funded by the Programa Operacional Regional do Norte (ON.2 - O Novo Norte), QREN, FEDER.

\section{REFERENCES}

1 Joseph B, Ramteke PW and Thomas G, Cold active microbial lipases: some hot issues and recent developments. Biotechnol Adv 26:457-470 (2008).

2 Kapoor M and Gupta MN, Lipase promiscuity and its biochemical applications. Process Biochem 47:555-569 (2012).

3 Houde A, Kademi A and Liblanc D, Lipases and their industrial applications. Appl Biochem Biotechnol 118:155-170 (2004).

4 Salihu A, Alam MZ, AbdulKarim MI and Salleh HM, Lipase production: an insight in the utilization of renewable agricultural residues. Resour Conserv Recycl 58:36-44 (2012).

5 Singh A and Mukhopadhyay M, Overview of fungal lipase: a review. Appl Biochem Biotechnol 166:486-520 (2012).

6 Pandey A, Solid-state fermentation. Biochem Eng J 13:81-84 (2003).

7 Díaz $A B$, Ildefonso C, Ory I and Blandino A, Evaluation of the conditions for the extraction of hydrolitic enzymes obtained by solid state fermentation from grape pomace. Enzyme Microb Technol 41:302-306 (2007).

8 Couto SR and Sanromán MÁ, Application of solid-state fermentation to food industry: a review. J Food Eng 76:291 - 302 (2006).

9 Contesini FJ, Lopes DB, Macedo GA, Nascimento MC and Carvalho PO, Aspergillus sp. lipase: potential biocatalyst for industrial use. J Mol Catal B Enzym 67:163-171 (2010).

10 Castilho LR, Polato CMS, Baruque EA, Sant'Anna J and Freire DMG, Economic analysis of lipase production by Penicillium restrictum in solid-state and submerged fermentations. Biochem Eng J 4:239-247 (2000).

11 INE, Olive oil produced by geographic location and type of olive mill (2015). [Online]. Available: https://www.ine.pt/xportal/xmain? xpid $=$ INE\&xpgid $=$ ine_indicadores\&indOcorrCod $=0000709 \&$ con texto $=$ bd\&selTab $=$ tab2 [27 October 2015].

12 FAO, Olive oil produced by Spain (2015). [Online]. Available: http://faostat3.fao.org [27 October 2015].

13 Alburquerque JA, Gonzálvez J, García D and Cegarra J, Measuring detoxification and maturity in compost made from 'alperujo', the solid by-product of extracting olive oil by the two-phase centrifugation system. Chemosphere 64:470-477 (2006).

14 Gavala HN, Skiadas IV, Ahring BK and Lyberatos G, Potential for biohydrogen and methane production from olive pulp. Water SCi Technol 52:209-215 (2005).

15 Borja R, Rincón B and Raposo F, Anaerobic biodegradation of two-phase olive mill solidwastes and liquid effluents: kinetic studies and process performance. J Chem Technol Biotechnol 81:1450-1462 (2006).

16 Li A, Antizar-Ladislao B and Khraisheh MAM, Bioconversion of municipal solid waste to glucose for bio-ethanol production. Bioprocess Biosyst Eng 30:189-196 (2007).

17 Ballesteros I, Oliva JM, Saez F and Ballesteros M, Ethanol production from lignocellulosic byproducts of olive oil extraction. Appl Biochem Biotechnol 91-93:237-252 (2001).

18 Ramos-Cormenzana A, Monteoliva-Sánchez M and López MJ, Bioremediation of alpechin. Int Biodeterior Biodegradation 35:249-268 (1995).

19 Salgado JM, Abrunhosa L, Venâncio A, Domínguez JM and Belo I, Screening of winery and olive mill wastes for lignocellulolytic enzyme production from Aspergillus species by solid-state fermentation. Biomass Convers Biorefinery 4:201 - 209 (2014).
20 Salgado JM, Abrunhosa L, Venâncio A, Domínguez JM and Belo I, Integrated use of residues from olive mill and winery for lipase production by solid state fermentation with Aspergillus sp. Appl Biochem Biotechnol 172:1832-1845 (2014).

21 Alburquerque JA, Gonzálvez J, García D and Cegarra J, Effects of bulking agent on the composting of 'alperujo', the solid by-product of the two-phase centrifugation method for olive oil extraction. Process Biochem 41:127-132 (2006).

22 Damaso MCT, Passianoto MA, De Freitas SC, Freire SC, Lago RCA and Couri S, Utilization of agroindustrial residues for lipase production by solid-state fermentation. Brazilian J Microbiol 39:676-681 (2008).

23 Falony G, Armas JC, Mendoza JCD and Hernández JLM, Production of extracellular lipase from Aspergillus niger by solid-state fermentation. Food Technol Biotechnol 44:235-240 (2006).

24 Apprich S, Tirpanalan Ö, Hell J, Reisinger M, Böhmdorfer S, Siebenhandl-Ehn S et al., Wheat bran-based biorefinery 2: Valorization of products. LWT - Food Sci Technol 56:222-231 (2014).

25 Gutarra MLE, Godoy MG, Maugeri F, Rodrigues MI, Freire DMG and Castilho LR, Production of an acidic and thermostable lipase of the mesophilic fungus Penicillium simplicissimum by solid-state fermentation. Bioresour Technol 100:5249-5254 (2009).

26 Serra R, Cabañes FJ, Perrone G, Castellá G, Venâncio A, Mulè G et al., Aspergillus ibericus: a new species of section Nigri isolated from grapes. Mycologia 98:295-306 (2006).

27 Abrunhosa L, Oliveira F, Dantas D, Gonçalves C and Belo I, Lipase production by Aspergillus ibericus using olive mill wastewater. Bioprocess Biosyst Eng 36:285-291 (2013).

28 Gomes N, Gonçalves C, García-Román M, Teixeira JA and Belo I, Optimization of a colorimetric assay for yeast lipase activity in complex systems. Anal Methods 3:1008-1013 (2011).

29 Alburquerque JA, González J, García D and Cegarra J, Agrochemical characterisation of 'alperujo', a solid by-product of the two-phase centrifugation method for olive oil extraction. Bioresour Technol 91:195-200 (2004).

30 Edwinoliver NG, Thirunavukarasu K, Naidu RB, Gowthaman MK, Kambe TN and Kamini NR, Scale up of a novel tri-substrate fermentation for enhanced production of Aspergillus niger lipase for tallow hydrolysis. Bioresour Technol 101:6791-6796 (2010).

31 Kumar S, Katiyar N, Ingle P and Negi S, Use of evolutionary operation (EVOP) factorial design technique to develop a bioprocess using grease waste as a substrate for lipase production. Bioresour Technol 102:4909-4912 (2011).

32 Sun SY and Xu Y, Solid-state fermentation for 'whole-cell synthetic lipase' production from Rhizopus chinensis and identification of the functional enzyme. Process Biochem 43:219-224 (2008).

33 Mahadik ND, Puntambekar US, Bastawde KB, Khire JM and Gokhale DV, Production of acidic lipase by Aspergillus niger in solid state fermentation. Process Biochem 38:715-721 (2002).

34 Singhania RR, Patel AK, Soccol CR and Pandey A, Recent advances in solid-state fermentation. Biochem Eng J 44:13-18 (2009).

$35 \mathrm{Pal} A$ and Khanum $\mathrm{F}$, Production and extraction optimization of xylanase from Aspergillus niger DFR-5 through solid-statefermentation. Bioresour Technol 101:7563-7569 (2010).

$36 \mathrm{Lu} \mathrm{W}, \mathrm{Li}$ D and Wu Y, Influence of water activity and temperature on xylanase biosynthesis in pilot-scale solid-state fermentation by Aspergillus sulphureus. Enzyme Microb Technol 32:305-311 (2003).

37 Imandi SB, Karanam SK and Garapati HR, Use of Plackett-Burman design for rapid screening of nitrogen and carbon sources for the production of lipase in solid state fermentation by Yarrowia lipolytica from mustard oil cake (Brassica napus). Brazilian J Microbiol 44:915-921 (2013).

38 Virupakshi S, Babu KG, Gaikwad SR and Naik GR, Production of a xylanolytic enzyme by a thermoalkaliphilic Bacillus sp. JB-99 in solid state fermentation. Process Biochem 40:431-435 (2005).

39 Hamidi-Esfahani Z, Shojaosadati SA and Rinzema A, Modelling of simultaneous effect of moisture and temperature on $A$. niger growth in solid-state fermentation. Biochem Eng J 21:265-272 (2004).

40 Colla LM, Rizzardi J, Pinto MH, Reinehr CO, Bertolin TE and Costa JAV, Simultaneous production of lipases and biosurfactants by submerged and solid-state bioprocesses. Bioresour Technol 101:8308-8314 (2010) 